\title{
Intima-media thickness correlates with features of metabolic syndrome in young people with a clinical diagnosis of familial hypercholesterolaemia
}

\author{
Małgorzata Waluś-Miarka', ${ }^{1,}$ Wiktoria Wojciechowska ${ }^{3}$, Przemysław Miarka ${ }^{4}$, Małgorzata Kloch-Badełek ${ }^{3}$, \\ Ewa Woźniakiewiczz', Danuta Czarnecka ${ }^{3}$, Marek Sanak ${ }^{5}$, Maciej Małecki ${ }^{1}$, Barbara Idzior-Waluś ${ }^{1}$ \\ 'Department of Metabolic Diseases, Jagiellonian University Medical College, Krakow, Poland \\ ${ }^{2}$ Department of Medical Didactics, Jagiellonian University Medical College, Krakow, Poland \\ ${ }^{3} 1^{\text {st }}$ Department of Cardiology and Hypertension, Jagiellonian University Medical College, Krakow, Poland \\ ${ }^{4}$ Department of Nephrology, Jagiellonian University Medical College, Krakow, Poland \\ ${ }^{5}$ Department of Molecular Biology and Clinical Genetics, Second Chair of Internal Medicine, \\ Jagiellonian University Medical College, Krakow, Poland
}

\begin{abstract}
A bstract
Background: Familial hypercholesterolaemia $(\mathrm{FH})$ is a monogenic lipid metabolism disorder characterised by markedly elevated serum low-density lipoprotein (LDL) cholesterol level due to a mutation in the LDL receptor gene. Clinical features of $\mathrm{FH}$ include premature atherosclerosis and coronary artery disease.

Aim: To explore associations between noninvasive markers of atherosclerosis including intima-media thickness (IMT) and pulse wave velocity (PWV) and blood lipids, blood pressure (BP) and obesity in a group of young patients with $\mathrm{FH}$.

Methods: Study population included 36 patients aged $<35$ years with the diagnosis of FH based on the Simon Broome Register criteria, and their 49 relatives who comprised the control group free of $\mathrm{FH}$.

Results: Mean IMT values were higher in FH patients than controls $(0.60 \pm 0.19$ vs. $0.53 \pm 0.07 \mathrm{~mm}$, respectively, $\mathrm{p}<0.05)$. Mean body mass index (BMI) and waist circumference were similar in patients and controls. The prevalence of carotid atherosclerotic plaques was significantly higher among FH patients $(n=6)$ than in controls $(n=1)(21.4 \%$ vs. $2.6 \%, p=0.012)$. Arterial hypertension was present in $27.8 \%$ of patients with $\mathrm{FH}$ and $16.3 \%$ of subjects in the control group. Systolic blood pressure (SBP) in FH patients correlated significantly with age $(r=0.35)$, BMI $(r=0.48)$ and waist circumference $(r=0.47)$, and diastolic blood pressure (DBP) correlated with BMI $(r=0.42)$ and waist circumference $(r=0.41)$. PWV correlated significantly with age $(r=0.44)$, SBP $(r=0.63)$ and DBP $(r=0.52)$. We did not find any correlations between IMT and serum lipids, BP or obesity indices in $\mathrm{FH}$ patients.

Conclusions: Our findings show a higher rate of arterial hypertension in young FH patients compared to their relatives free of $\mathrm{FH}$, with significant associations between BP and indices of obesity and arterial stiffness. Intensive lipid lowering and antihypertensive therapy along with a reduction in central fat may be considered a mandatory treatment strategy in young $\mathrm{FH}$ patients to prevent atherosclerosis and increased arterial stiffness.

Key words: familial hypercholesterolaemia, atherosclerosis, carotid intima-media thickness
\end{abstract}

Kardiol Pol 2013; 71, 6: 566-572

Address for correspondence:

Małgorzata Waluś-Miarka, MD, PhD, Department of Metabolic Diseases, Jagiellonian University Medical College, ul. Kopernika 15, 31-501 Kraków, Poland,

e-mail:mmwalus@wp.pl

Received: 01.06.2012 Accepted: 16.01.2013

Copyright (C) Polskie Towarzystwo Kardiologiczne 


\section{INTRODUCTION}

Heterozygous familial hypercholesterolaemia $(\mathrm{HeFH})$ occurs at a rate of $1 / 500$ in the general population and is one of the most common monogenic autosomal dominant disorders. Clinical and laboratory features of HeFH included elevated serum total cholesterol and low-density lipoprotein cholesterol (LDL-C) levels, tendinous xanthomas, arcus senilis of the cornea and xanthelasma palpebrarum [1, 2]. However, the most serious clinical manifestation is premature coronary atherosclerosis and ischaemic heart disease (IHD). About 50\% of untreated men with HeFH develop IHD before 55 years of age, and women develop IHD on average 9 years later than men. Mortality among patients with $\mathrm{HeFH}$ is significantly increased compared to healthy subjects of the same age and gender. Numerous studies showed that long-term lipid-lowering therapy with statins reduces coronary deaths and overall mortality in these patients [3-5]. Other major IHD risk factors in this population include arterial hypertension, low high-density lipoprotein cholesterol (HDL-C) level, diabetes and abdominal obesity.

In subjects without overt IHD, noninvasive evaluation of the severity and progression of atherosclerosis may be accomplished with measurements of carotid intima-media thickness (IMT) and arterial stiffness.

The aim of this study was to evaluate IHD risk factors (serum lipids, blood pressure, and obesity) and their relation to carotid IMT, a noninvasive marker of atherosclerosis, and pulse wave velocity (PWV), a marker of arterial stiffness, in young subjects with $\mathrm{HeFH}$.

\section{METHODS \\ Study group}

Study population included 36 young patients (aged $<35$ years) with the diagnosis of HeFH based on the Simon Broome Register criteria, and their 49 age- and gender-matched relatives without $\mathrm{HeFH}$. We included patients with both definitive and probable HeFH [6, 7]. The Simon Broome Register criteria for the diagnosis of $\mathrm{HeFH}$ are shown in Table 1. Exclusion criteria included severe liver or kidney disease and hypothyroidism. In all patients, clinical history was taken using a standardised questionnaire that included symptoms of IHD, other cardiovascular disease, history of smoking, and treatment used. Hypertension was defined as blood pressure $\geq 140 / 90 \mathrm{~mm} \mathrm{Hg}$ or the use of antihypertensive drugs. The study was approved by the Bioethics Committee at the Jagiellonian University Medical College.

\section{Lipid levels}

Blood for determination of lipid parameters was taken under fasting conditions. Serum lipid levels were measured by enzymatic methods using Roche kits. LDL-C level was estimated using the Friedewald formula.
Table 1. Diagnostic criteria for familial hypercholesterolaemia (FH) according to the Simon Broome Register Group

\section{Definite diagnosis of FH}

a. Total cholesterol $>7.5 \mathrm{mmol} / \mathrm{L}(290 \mathrm{mg} / \mathrm{dL})$ in adults or total cholesterol $>6.7 \mathrm{mmol} / \mathrm{L}(260 \mathrm{mg} / \mathrm{dL})$ in children below 16 years of age

OR

$\mathrm{LDL}$ cholesterol $>4.9 \mathrm{mmol} / \mathrm{L}(190 \mathrm{mg} / \mathrm{dL})$ in adults

( $4.0 \mathrm{mmol} / \mathrm{L}$ in children)

PLUS

b. Tendon xanthomas in patient or in $1^{\text {st }}$ or $2^{\text {nd }}$ degree relative (parent, child, sibling, grandparent, uncle, aunt) $\mathrm{OR}$

c. Molecular diagnosis of FH based on the identification of apolipoprotein B or LDL receptor mutation

\section{Probable diagnosis of FH: (a) PLUS (d) OR (e)}

d. Family history of myocardial infarction below 50 years of age in a $2^{\text {nd }}$ degree relative (grandparent, uncle, aunt) or below 60 years of age in a $1^{\text {st }}$ degree relative (parent, sibling, child)

e. Family history of elevated total cholesterol: $>7.5 \mathrm{mmol} / \mathrm{L}$ $(290 \mathrm{mg} / \mathrm{dL})$ in adult $1^{\text {st }}$ or $2^{\text {nd }}$ degree relative or $>6.7 \mathrm{mmol} / \mathrm{L}$ $(260 \mathrm{mg} / \mathrm{dL})$ in child or sibling aged below 16 years

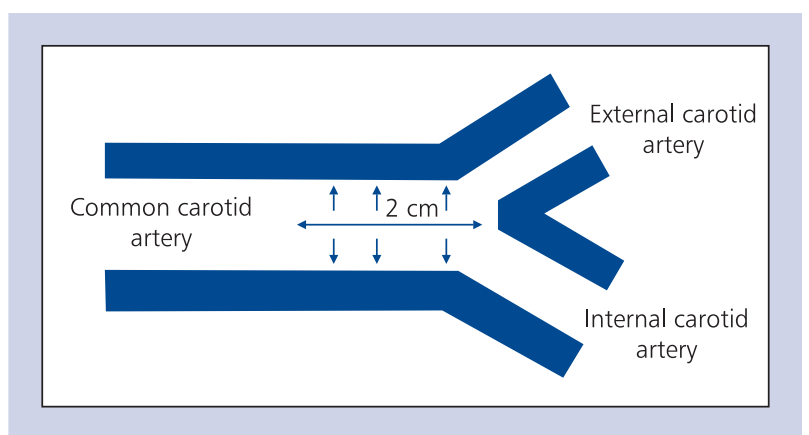

Figure 1. Intima-media thickness (IMT) measurements in the common carotid artery

\section{Carotid artery ultrasonography}

The degree of vascular remodelling was evaluated by ultrasonographic IMT measurements in the common carotid artery. Measurements were performed manually in the two-dimensional long-axis view using a linear $10 \mathrm{MHz}$ probe (GE VIVID 7 ultrasound machine). IMT was measured within near and far walls of both common carotid arteries, $2 \mathrm{~cm}$ proximally to the bifurcation into the internal and external carotid arteries (Fig. 1). All IMT measurements were performed by two experienced and knowledgeable operators (previously trained and evaluated in research core laboratories for the evaluation and analysis of IMT) who were blinded to the clinical characteristics of the study subjects. Three 
Table 2. Study group characteristics

\begin{tabular}{|c|c|c|c|}
\hline Parameter & Patients with HeFH & Control group & $\mathbf{P}$ \\
\hline Age [years] & $27.3 \pm 6.6$ & $25.2 \pm 6.7$ & NS \\
\hline Body mass index $\left[\mathrm{kg} / \mathrm{m}^{2}\right]$ & $23.6 \pm 3.9$ & $23.2 \pm 4.5$ & NS \\
\hline Waist circumference [cm] & $80.4 \pm 12.5$ & $80.12 \pm 12.7$ & NS \\
\hline Waist-to-hip ratio & $0.81 \pm 0.09$ & $0.82 \pm 0.08$ & NS \\
\hline $\mathrm{SBP}[\mathrm{mm} \mathrm{Hg}]$ & $120.4 \pm 16.2$ & $121.4 \pm 16.8$ & NS \\
\hline $\mathrm{DBP}[\mathrm{mm} \mathrm{Hg}]$ & $75.11 \pm 11.06$ & $77.9 \pm 10.15$ & NS \\
\hline Hypertension & $10(27.8 \%)$ & $8(16.3 \%)$ & NS \\
\hline HDL cholesterol [mmol/L] & $1.49 \pm 0.32$ & $1.59 \pm 0.82$ & NS \\
\hline LDL cholesterol [mmol/L] & $5.42 \pm 1.82$ & $3.22 \pm 0.98$ & $<0.001$ \\
\hline Pulse wave velocity $[\mathrm{m} / \mathrm{s}]$ & $8.4 \pm 1.5$ & $8.5 \pm 1.1$ & NS \\
\hline Intima-media thickness [mm] & $0.60 \pm 0.19$ & $0.53 \pm 0.07$ & 0.047 \\
\hline Presence of carotid atherosclerotic plaques & $6(21.4 \%)$ & $1(2.6 \%)$ & 0.012 \\
\hline
\end{tabular}

Mean values \pm SD are given unless stated otherwise; HeFH — heterozygous familial hypercholesterolaemia; SBP — systolic blood pressure; $\mathrm{DBP}$ — diastolic blood pressure; HDL — high-density lipoprotein; LDL — low-density lipoprotein

measurements were performed at each arterial site. We evaluated both the mean of these three measurements and maximum IMT. Common carotid artery IMT > $0.9 \mathrm{~mm}$ was considered abnormal [8]. The number, size, and morphology of atherosclerotic plaques were described if such lesions were present. If an atherosclerotic plaque was present within the IMT evaluation area, measurements were limited to evaluation of the plaque and IMT measurement within the contralateral wall. Atherosclerotic plaques were defined as IMT $>1.5 \mathrm{~mm}$ or focal IMT increase by $0.5 \mathrm{~mm}$ or $50 \%$ of the IMT in the adjacent vascular segment [8]. Evaluation of intra-observer and inter-observer variability was performed in the early phase of study by calculating correlation coefficients for the initial ten patients. In these calculations, intra-observer variability was 0.96 and 0.94 , respectively, and inter-observer variability was 0.90 . In our study group, no patients were excluded due to suboptimal quality of ultrasonographic images.

\section{Evaluation of arterial stiffness}

Arterial stiffness was evaluated by measurements of PWV between the carotid and femoral artery. The Complior device with a Fukuda sensor was used for these measurements.

\section{Statistical analysis}

Results obtained in the HeRH and control groups were compared using the Mann-Whitney test. Associations between the studied variables were evaluated using the Pearson linear correlation coefficient. Finally, a multiple regression model was created by stepwise regression. $\mathrm{P} \leq 0.05$ was considered statistically significant. Statistical analyses were performed using the STATISTICA 10 package.
Table 3. Linear correlation coefficients between blood pressure and indices of obesity in patients with heterozygous familial hypercholesterolaemia

\begin{tabular}{|lccc|}
\hline & Parameter & $\mathbf{r}$ & $\mathbf{p}$ \\
\hline Systolic blood pressure & Age & 0.35 & 0.04 \\
& BMI & 0.48 & 0.003 \\
& WC & 0.47 & 0.004 \\
Diastolic blood pressure & WHR & 0.47 & 0.004 \\
& BMI & 0.47 & 0.01 \\
& WC & 0.41 & 0.01 \\
& WHR & 0.37 & 0.03 \\
\hline
\end{tabular}

BMI — body mass index; WC - waist circumference; WHR - waist-to-hip ratio

\section{RESULTS}

We studied 36 patients with a clinical diagnosis of $\mathrm{HeFH}$ and their 49 healthy relatives with normal serum lipid levels. Characteristics of the studied subjects are shown in Table 2. As expected, mean LDL-C levels in patients with HeFH were significantly higher compared to healthy relatives. Mean IMT values were also higher in patients with HeFH compared to controls. Mean body mass index (BMI) and waist circumference was similar in patients and relatives. Atherosclerotic plaques in the carotid arteries were observed significantly more frequently in patients with HeFH. In contrast, PWV values were similar in patients with $\mathrm{HeFH}$ and controls. Rates of hypertension were also similar in both groups. Smoking was reported by 15 subjects in the control group and only 2 patients with $\mathrm{HeFH}$. Only $30 \%$ of patients with $\mathrm{HeFH}$ were treated with statins. Table 3 shows correlation coefficients for 
Table 4. Linear correlation coefficients between pulse wave velocity (PWV), blood pressure, and lipid parameters in the overall study population, patients with heterozygous familial hypercholesterolaemia $(\mathrm{HeFH})$, and subjects without $\mathrm{HeFH}$

\begin{tabular}{|lccc|} 
& Parameter & $\mathbf{r}$ & $\mathbf{p}$ \\
\hline PWV, overall & Age & 0.38 & 0.001 \\
& WC & 0.30 & 0.01 \\
PWV, HeFH & SBP & 0.43 & 0.000 \\
& DBP & 0.41 & 0.001 \\
& Age & 0.44 & 0.016 \\
PWV, no HeFH & SBP & 0.63 & 0.000 \\
& DBP & 0.53 & 0.003 \\
& LDL-C & 0.41 & 0.011 \\
& Age & 0.38 & 0.018 \\
& WC & 0.42 & 0.008 \\
\hline
\end{tabular}

WC - waist circumference; SBP — systolic blood pressure; DBP — diastolic blood pressure; LDL-C — low-density lipoprotein cholesterol

Table 5. Linear correlation coefficients between mean intima-media thickness (IMT) and other evaluated parameters in the overall study population, patients with heterozygous familial hypercholesterolaemia $(\mathrm{HeFH})$, and subjects without $\mathrm{HeFH}$

\begin{tabular}{|lccc|} 
& Parameter & $\mathbf{r}$ & $\mathbf{p}$ \\
\hline IMT, overall & Age & 0.37 & 0.002 \\
& LDL-C & 0.27 & 0.03 \\
IMT, no HeFH & WC & 0.20 & NS \\
& Age & 0.512 & 0.001 \\
IMT, HeFH & WC & 0.312 & 0.05 \\
& LDL-C & 0.01 & NS \\
& Age & 0.31 & NS \\
& LDL-C & 0.132 & NS \\
& WC & 0.175 & NS \\
\hline
\end{tabular}

WC — waist circumference; LDL-C — low-density lipoprotein cholesterol

relations between blood pressure and other evaluated variables. In patients with $\mathrm{HeFH}$, systolic blood pressure (SBP) correlated significantly with age, BMI, waist circumference and waist-to-hip ratio, and diastolic blood pressure (DBP) correlated with BMI, waist circumference and waist-to-hip ratio. As expected, these correlations between blood pressure and indices of obesity were also significant in healthy controls.

The index of arterial stiffness, PWV, correlated significantly with age, SBP, and DBP in patients with HeFH (Table 4). In the overall study population, PWV correlated with age, waist circumference, SBP, and DBP. A correlation between PWV and LDL-C level was observed only in healthy controls.

In the overall study population, we found that IMT, an established index of severity of vascular atherosclerotic lesions, significantly correlated with LDL-C level and age (Table 5). In
Table 6. Stepwise multiple regression models

\begin{tabular}{|c|c|c|c|}
\hline & b & SE & p \\
\hline \multicolumn{4}{|c|}{$\begin{array}{l}\text { Dependent variable - mean IMT; independent variables: HDL-C, } \\
\text { LDL-C, age, waist circumference, SBP, and DBP }\end{array}$} \\
\hline Intercept & 0.368 & 0.084 & 0.000 \\
\hline Age & 0.010 & 0.002 & 0.000 \\
\hline LDL-C & 0.016 & 0.007 & 0.035 \\
\hline HDL-C & -0.075 & 0.036 & 0.040 \\
\hline \multicolumn{4}{|c|}{$\begin{array}{l}\text { Dependent variable - mean PVW; independent variables: } \\
\text { HDL-C, LDL-C, age, waist circumference, SBP, and DBP }\end{array}$} \\
\hline Intercept & 3.663 & 1.103 & 0.001 \\
\hline SBP & 0.028 & 0.008 & 0.001 \\
\hline Age & 0.063 & 0.022 & 0.006 \\
\hline LDL-C & -0.083 & 0.074 & 0.263 \\
\hline
\end{tabular}

SE — standard error; IMT — intima-media thickness; HDL-C — high-density lipoprotein cholesterol; LDL-C — low-density lipoprotein cholesterol; SBP — systolic blood pressure; DBP — diastolic blood pressure; PWV - pulse wave velocity

contrast, patients with HeFH showed no correlations between IMT and lipid levels or age, and between lipid levels and blood pressure or obesity indices.

In the stepwise multiple regression model with IMT as the dependent variable and age, LDL-C, HDL-C, waist circumference, SBP, and DBP as the independent variables showed that only age, LDL-C, and HDL-C were significant predictors of IMT, contributing to $31 \%$ of IMT variability. Age was the only significant predictor of IMT in subgroups of HeFH patients and controls, which might have been related to a small number of subjects in both these groups. In the regression model with PWV as the dependent variable, significant predictors included age and SBP in the overall study population, SBP in patients with $\mathrm{HeFH}$, and age, waist circumference, and LDL-C level in healthy relatives (Table 6).

\section{DISCUSSION}

With the estimated rate of $1 / 500$ in the general population, $\mathrm{HeFH}$ may be expected to affect about 70,000 persons in Poland but many such cases remain undetected, and many patients with established $\mathrm{HeFH}$ do not receive appropriate treatment. In our study group, the diagnosis of HeFH was based on the Simon Broome Register criteria which are used in everyday cardiology and general practice. The Polish Cardiac Society currently recommends, in accordance with the advice of an European Atherosclerosis Society and European Society of Cardiology expert panel, that the diagnosis of $\mathrm{HeFH}$ be made using clinical and biochemical criteria [9, 10].

In our study group, patients with a clinical suspicion of $\mathrm{FH}$ were characterised by increased IMT and a higher rate of carotid atherosclerotic plaques compared to age-matched young subjects with normal cholesterol level. In addition, 
these young patients showed a higher rate of hypertension which was also related to obesity indices.

Carotid IMT is an established surrogate marker of the presence and severity of atherosclerotic plaques, and non-invasive carotid IMT measurements are frequently used to evaluate atherosclerotic lesions [11, 12]. They were also shown to correlate with other indices of atherosclerosis severity such as computed tomography-based calcium score [13]. Significantly higher IMT values and the presence of atherosclerotic plaques identified in the study subjects indicate an advanced atherosclerotic process in this population, as also reported by other authors $[14,15]$. Carotid ultrasonography is prone to measurement errors (imprecise detection) and observations in small patient samples, such as in our study, may be chance findings but we attempted to minimise such biases by performing highly standardised measurements and evaluating intra- and inter-observer variability.

Significant correlations between IMT and age, BMI, waist circumference, SBP and DBP were reported by Ye et al. [16]. These authors also found correlations between carotid IMT and triglyceride, apolipoprotein B, and glucose levels, and the cholesterol-year score. A metaanalysis of 51 studies showed that total and LDL-C levels were significant predictors of femoral artery IMT in patients with $\mathrm{HeFH}$, and of carotid artery IMT in subjects with familial combined hyperlipidaemia [17]. In this metaanalysis, reported by Masoura et al. [17], carotid IMT was found to be significantly higher in subjects with HeFH compared to the control group with normal lipid parameters. Overall, the mean IMT difference in all included studies was $0.12 \mathrm{~mm}(95 \% \mathrm{Cl}$ 0.09-0.15). Our observation of a higher prevalence of atherosclerotic plaques in patients with $\mathrm{HeFH}$ is also confirmed by the metaanalysis of Masoura et al. [17], although it should be noted that our analysis was limited to young subjects. Also similarly to our study, in the metaanalysis by Masoura et al. [17]. IMT was found to correlate with subject age but not with serum lipid levels. The authors concluded that these findings suggested that the most important factor affecting IMT was the duration of exposure to the harmful effects of elevated cholesterol levels, and thus age was a stronger predictor of IMT than cholesterol level in these patients.

Ye et al. [16] also noted a significant correlation between the cholesterol-year score and IMT, but in those patients with a molecular diagnosis of HeFH, IMT showed a correlation with an inflammation marker, high sensitivity C-reactive protein level.

In the recent years, IMT has been frequently used as a surrogate marker of atherosclerosis and a predictor of myocardial infarction and stroke. In a metaanalysis of 8 studies involving asymptomatic subjects, an increase of IMT by $0.1 \mathrm{~mm}$ was found to be associated with an increase in the adjusted risk of myocardial infarction by $10 \%$, and of stroke by $14 \%$ [18] Taking into account the fact that only $30 \%$ of our patients with HeFH were treated with statins, our findings confirm the need for more aggressive identification of young subjects with $\mathrm{HeFH}$ and earlier initiation of treatment in these patients.

In a study of 12 patients with HeFH, Bellanger et al. [19] showed a reverse association between cholesterol efflux mediated by HDL2-dependent scavenger receptor-B1 and ABCG1 and IMT. These results suggest a major role of HDL in the pathogenesis of vascular lesions in patients with HeFH. In our regression analysis, $\mathrm{HDL}-\mathrm{C}$ level correlated negatively with IMT, which is consistent with findings by Bellanger et al. [19].

Results of our study showed a high rate of hypertension among patients with $\mathrm{HeFH}$. We also found a significant association between PWV and blood pressure, although similar PWV was noted in patients and controls. In a group of children with familial and polygenic hypercholesterolaemia, whose average age was 10 years, Italian authors found higher PWV compared to the control group, while IMT values were similar in those children with hypercholesterolaemia and controls [20]. In addition, cholesterol level showed an association with PWV in that population but children with elevated blood pressure were excluded from the study.

In a study of 436 subjects with LDL receptor defects, higher blood pressure values were observed compared to the control group [11]. In our patients with $\mathrm{HeFH}$, blood pressure showed expected correlations with age and indices of obesity including waist circumference and waist-to-hip ratio. These findings suggest that in addition to lipid-lowering therapy, antihypertensive drug therapy along with strategies to reduce abdominal fat (diet and physical activity) have an important role in prevention of atherosclerosis and increased arterial stiffness in this patient population. Emerging data of importance for prevention of hypertension indicate that infections may also be related to elevated blood pressure in these patients [21]. Studies on molecular defects underlying $\mathrm{HeFH}$ are also important for prevention of IHD. Junyent et al. [11] reported a significant association between carotid IMT and the type of LDL receptor mutation, which highlights the role of the genetic evaluation of HeFH beyond providing a secure diagnosis, although not all authors confirmed such a relationship [22].

Despite the fact that smoking was reported by 2 patients with $\mathrm{HeFH}$ and 15 subjects in the control group, IMT values were found to be significantly higher in patients compared to controls, which also emphasizes the risk associated with lipid abnormalities and hypertension.

\section{CONCLUSIONS}

Young patients with a clinical suspicion of familial hypercholesterolaemia were characterised by expectedly higher LDL-C levels, along with higher IMT values and a higher rate of carotid atherosclerotic plaques compared to age-matched young subjects with normal cholesterol level. Prevalence of hypertension was also higher in patients with HeFH compared to the control group, and blood pressure values correlated with indices of 
obesity including waist circumference, BMI, and waist-to-hip ratio. Our findings suggest that in addition to lipid-lowering therapy, antihypertensive drug therapy along with strategies to reduce abdominal fat (diet and physical activity) have an important role in prevention of atherosclerosis and increased arterial stiffness in this patient population.

Project received financial support from National Science Centre Poland; number N N404 070933 based on decision number 0709/B/P01/2007/33.

\section{Conflict of interest: none declared}

\section{References}

1. Brown MS, Goldstein JL. A receptor mediated pathway for cholesterol homeostasis. Science, 1986; 232: 34-47.

2. Rader DJ, Cohen J, Hobbs HH. Monogenic hypercholesterolemia: new insights in pathogenesis and treatment. J Clin Invest, 2003, 111: 795-1803.

3. Versmissen J, Oosterveer DM, Yazdanpanah $\mathrm{M}$ et al. Efficacy of statins in familial hypercholesterolaemia: a long term cohort study. BMJ, 2008; 337: a2423.

4. Neil A, Cooper J, Betteridge J et al. Reductions in all-cause, cancer and coronary mortality in statin-treated patients with heterozygous familial hypercholesterolemia: a prospective study. Eur Heart J, 2008; 29: 2625-2633.

5. Avellone G, Di Garbo V, Guarnotta V et al. Efficacy and safety of long-term ezetimibe/simvastatin treatment in patients with familial hypercholesterolemia. Int Angiol 2010; 29: 514-524.

6. Scientific Steering Committee on behalf of the Simon Broome Register Group. Risk of fatal coronary heart disease in familial hypercholesterolemia. BMJ, 1991; 303: 893-896.

7. Idzior-Waluś B, Sanak M, Starzyk J et al. Autosomalna dominująca hipercholesterolemia — niedoceniony problem diagnostyczny i kliniczny. Kardiol Pol, 2009; 67: 1015-1022.

8. Management of Arterial Hypertension of the European Society of Hypertension; European Society of Cardiology. 2007 Guidelines for the Management of Arterial Hypertension: The Task Force for the Management of Arterial Hypertension of the European Society of Hypertension (ESH) and of the European Society of Cardiology (ESC). J Hypertens, 2007; 25: 1105-1187.

9. Grupa Robocza do spraw posteppowania w dyslipidemiach Europejskiego Towarzystwa Kardiologicznego (ESC) i Europejskiego Towarzystwa Miażdżycowego (EAS). Wytyczne ESC/EAS dotyczące postępowania w dyslipidemiach. Kardiol Pol, 2011; 69 (suppl. IV): S143-S200.

10. European Association for Cardiovascular Prevention \& Rehabilitation, Reiner Z, Catapano AL, De Backer G et al.; ESC Committee for Practice Guidelines (CPG) 2008-2010 and 2010-2012 Committees. ESC/EAS Guidelines for the management of dyslipidaemias: the Task Force for the management of dyslipidaemias of the European Society of Cardiology (ESC) and the European Atherosclerosis Society (EAS). Eur Heart J, 2011; 32: 1769-1818.

11. Junyent M, Gilabert R, Jarauta E et al. Impact of low-density lipoprotein receptor mutational class on carotid atherosclerosis in patients with familial hypercholesterolemia. Atherosclerosis, 2010; 208: 437-441.

12. O'Leary DH, Polak JF, Kronmal RA et al. Carotid-artery intima and media thickness as a risk factor for myocardial infarction and stroke in older adults. Cardiovascular Health Study Collaborative Research Group. N Engl J Med, 1999; 340: 14-22.

13. Sillesen H, Muntendam P, Adourian A et al. Carotid plaque burden as a measure of subclinical atherosclerosis: comparison with other tests for subclinical arterial disease in the High Risk Plaque BioImage study. J Am Coll Cardiol Cardiovasc Imaging, 2012; 5: 681-689.

14. Wendelhag I, Wiklund O, Wikstrand J. Arterial wall thickness in familial hypercholesterolemia. Ultrasound measurement of intima-media thickness in the common carotid artery. Arterioscler Thromb, 1992; 12: 70-77.

15. Tonstad S, Joakimsen O, Stensland-Bugge E et al. Carotid intima-media thickness and plaque in patients with familial hypercholesterolaemia mutations and control subjects. Eur J Clin Invest, 1998; 28: 971-979.

16. Ye ZX, Cheng HM, Chiou KR et al. Relation of C-reactive protein and carotid intima media thickness in Taiwanese with familial hypercholesterolemia. Am J Cardiol, 2008; 102: 184-187.

17. Masoura C, Pitsavos C, Aznaouridis K et al. Arterial endothelial function and wall thickness in familial hypercholesterolemia and familial combined hyperlipidemia and the effect of statins. A systematic review and meta-analysis. Atherosclerosis, 2011; 214: 129-138.

18. Lorenz MW, Markus HS, Bots ML et al. Prediction of clinical cardiovascular events with carotid intima-media thickness: a systematic review and meta-analysis. Circulation, 2007; 115: 459-467.

19. Bellanger N, Orsoni A, Julia Z et al. Atheroprotective reverse cholesterol transport pathway is defective in familial hypercholesterolemia. Arteriscler Thromb Vasc Biol, 2011; 31: 1675-1981.

20. Riggio S, Mandraffino G, Sardo MA et al. Pulse wave velocity and augmentation index, but not intima-media thickness, are early indicators of vascular damage in hypercholesterolemic children. Eur J Clin Invest, 2010; 40: 250-257.

21. Vieira CL, Cury PR, Miname MH et al. Severe periodontitis is associated with diastolic blood pressure elevation in individuals with heterozygous familial hypercholesterolemia: a pilot study. J Periodontol, 2011; 82: 683-688.

22. Souverein OW, Defesche JC, Zwinderman AH et al. Influence of LDL-receptor mutation type on age at first cardiovascular event in patients with familial hypercholesterolaemia. Eur Heart J, 2007; 28: 299-304. 


\title{
Grubość kompleksu błona wewnętrzna- -błona środkowa tętnicy szyjnej koreluje z cechami zespołu metabolicznego u osób młodych z kliniczną diagnozą rodzinnej hipercholesterolemii
}

\author{
Małgorzata Waluś-Miarka' ${ }^{1,2}$, Wiktoria Wojciechowska ${ }^{3}$, Przemysław Miarka ${ }^{4}$, Małgorzata Kloch-Badełek ${ }^{3}$, \\ Ewa Woźniakiewicz ${ }^{1}$, Danuta Czarnecka ${ }^{3}$, Marek Sanak ${ }^{5}$, Maciej Małecki ${ }^{1}$, Barbara Idzior-Waluś ${ }^{1}$ \\ ${ }^{1}$ Klinika Chorób Metabolicznych, Uniwersytet Jagielloński, Collegium Medicum, Kraków \\ 2Zakład Dydaktyki Medycznej, Uniwersytet Jagielloński, Collegium Medicum, Kraków \\ 3/ Klinika Kardiologii i Nadciśnienia Tętniczego, Uniwersytet Jagielloński, Collegium Medicum, Kraków \\ ${ }^{4}$ Klinika Nefrologii, Uniwersytet Jagielloński, Collegium Medicum, Kraków \\ 5II Klinika Chorób Wewnętrznych, Zakład Genetyki, Uniwersytet Jagielloński, Collegium Medicum, Kraków
}

\section{Streszczenie}

Wstęp: Rodzinna heterozygotyczna hipercholesterolemia (RHH) jest monogenowym zaburzeniem metabolizmu lipidów cechującym się znacznym podwyższeniem stężenia cholesterolu LDL w wyniku mutacji w genie receptora LDL. RHH występuje z częstością ok. 1/500 osób w populacji. W Polsce RHH dotyczy ok. 70000 chorych, jednak znaczna ich część pozostaje niezdiagnozowana, a osoby z ustalonym rozpoznaniem często nie są leczone lub leczone nieadekwatnie. Charakterystyczne cechy kliniczne RHH obejmują podwyższenie stężenia cholesterolu całkowitego i cholesterolu LDL w surowicy, zmiany skórne o typie żółtaków ścięgien prostowników palców, ścięgna Achillesa, rąbek starczy oraz żółtaki powiek. Najgroźniejszym objawem klinicznym RHH jest przedwczesna miażdżyca naczyń wieńcowych i choroba niedokrwienna serca. Umieralność nieleczonych pacjentów z RHH jest znacznie większa niż osób zdrowych tej samej płci i wieku.

Cel: W niniejszym badaniu oceniono związek między grubością błony intima-media (IMT) i prędkością fali tętna, nieinwazyjnymi markerami miażdżycy naczyń a stężeniem lipidów, ciśnieniem tętniczym krwi i otyłością w grupie młodych pacjentów z RHH.

Metody: Badaniem objęto 36 młodych pacjentów z rozpoznaniem RHH na podstawie kryteriów Simon Broome Register, w wieku < 35 lat i ich 49 krewnych bez RHH, stanowiących grupę kontrolną, dobraną pod względem wieku i płci. U wszystkich chorych przeprowadzono wywiad wg standardowego kwestionariusza, obejmujący dane na temat obecności choroby niedokrwiennej serca, chorób układu sercowo-naczyniowego, nałogu palenia tytoniu oraz sposobu leczenia.

Wyniki: Średnie wartości IMT były wyższe u osób z RHH niż w grupie kontrolnej: 0,60 $\pm 0,19$ vs. 0,53 $\pm 0,07$ mm ( $p<0,05)$. Średnie wartości wskaźnika masy ciała (BMI) i obwód pasa były podobne w obu grupach. Pacjenci z RHH cechowali się częstszym występowaniem blaszek miażdżycowych $(n=6)$ niż grupa kontrola $(n=1)(21,4 \%$ vs. $2,6 \% ; p=0,012)$. Nadciśnienie tętnicze występowało u 27,8\% pacjentów z RHH i u 16,3\% osób z grupy kontrolnej. Ciśnienie skurczowe u osób z RHH korelowało istotnie z wiekiem $(r=0,35)$, BMI $(r=0,48)$ i obwodem pasa $(r=0,47)$, a ciśnienie rozkurczowe z BMI $(r=0,42)$ i obwodem pasa $(r=0,41)$. Prędkość fali tętna korelowała istotnie z wiekiem $(r=0,44)$, ciśnieniem skurczowym $(r=0,63)$ i rozkurczowym $(r=0,52)$. Nie zaobserwowano korelacji między IMT a stężeniem lipidów surowicy, ciśnieniem tętniczym lub wskaźnikami otyłości u pacjentów z RHH. Wnioski: Wyniki wskazują, że odsetek osób z nadciśnieniem tętniczym jest wyższy u młodych pacjentów z RHH niż u krewnych bez RHH oraz na obecność silnej korelacji między ciśnieniem tętniczym a wskaźnikami otyłości (takimi jak obwód pasa, BMI, współczynnik pas/biodra) oraz sztywnością naczyń. Intensywne leczenie hipolipemizujące i hipotensyjne, a także zmniejszenie otyłości brzusznej wydają się ważnymi elementami leczenia młodych pacjentów z RHH w celu prewencji miażdżycy i sztywnienia naczyń.

Słowa kluczowe: rodzinna hipercholesterolemia, miażdżyca, szyjna IMT

Kardiol Pol 2013; 71, 6: 566-572 